https://doi.org/10.48009/2_iis_2010_37-43

\title{
A DISTANCE LEARNING MODEL OF TEACHING UNIVERSITY COURSES IN THE THIRD WORLD COUNTRIES
}

\author{
Hae Yeon Choi, Savannah State University, choi@savannahstate.edu
}

\begin{abstract}
This research attempts to design how professors from U.S. and Korea can support college and university students in a third world country. As an information systems (IS) professor in a historically black colleges and universities (HBCU) in the south, the author has experienced many times over the number of years that some U.S. college students are having difficulties to buy their textbooks for the courses they take. However, in this case, they mostly seemed to have priority problems about what they have to purchase, for example, textbooks, or other things that they want to have. However, with some third world countries of Cambodia and Mongolia, even serious college students for their learning have very difficulties in finding financial resources to buy their textbooks. Along with this poor teaching and learning environments, effectively teaching university courses seems to be impossible at the first glance, but administrators, staffs, and faculty members are very eager to provide better teaching and learning environments for their students. At the same time students are really interested in, for example, learning more advanced IS knowledge and skills coming from developed countries. Thus this research focuses on two aspects: one is to let other college professors know about this, thereby some of them may join in this project for teaching those students in the future. The other is to design an effective teaching model for the university students in the third world countries.
\end{abstract}

Keywords: Mongolian University, Online Course, Global Text Project, Distance Learning

\section{OVERVIEW}

First objective of this pedagogy research is to publicize about universities in Mongolia and Cambodia, especially a Mongolian university, to college and university professors in the conference so that as many professors as possible may know about this, thereby hopefully they participate in the process of knowledge transfer from developed countries like US, Canada, England, Japan, Europe, Korea, etc. to university students in less developed countries like Cambodia, Ethiopia, and particularly Mongolia.
Thus we may support the university students so that students' basic and fundamental human demand for education quality and learning environments can be met.

Mongolia is a social democratic nation which became an independent one in 1990 from the former Soviet Union. According to Mongolian National Statistical Office, there are about 110 public and private universities and colleges. As of the end of 2004, out of about 2.7 million of its population, 700,000 to 1 million people live in its capital city, Ulaanbaatar. Thus educational system is heavily concentrated in the capital city. Without any specific distinction among elementary, middle and high schools, students learn in the same classroom of the same building for 11 years to complete up to their high school diploma.

As you notice the length of their educational system is one year shorter than that of America. After that students apply to a college or university. Private schools have been established by Russians and Chinese governments, where students have been taught in Russian and Chinese, respectively. However, Mongolian language called Khalkha is the official language, which is used by over $90 \%$ of its people. The script is expressed in Cyrillic which is a Russian alphabet [1]. After Mongolian independence from the former Soviet Union, some of private universities have been established by Christian missionaries or organizations.

According to World Education News \& Reviews (WENR), The Ministry of Science, Technology, Education, and Culture (MOSTEC) has approved about 100 private colleges and universities in Mongolia since 1990, which offer majors like economics, management, law, information and communication technologies, computer science, languages and performing and fine arts [2]. On the other hand, The CIA World Factbook reported that in 2007 national per capita income for Mongolia and its neighboring countries such as Russia, Kazakhstan, and China were \$2,900, \$14,600, \$10,658, and $\$ 2,800$, respectively [3].

Interestingly enough, Mongol's per capita GDP was higher than that of China. Nonetheless, Mongolia 
lacks infrastructure in its paved road, information system, educational system, etc. to name a few. Especially college students study without textbooks. Since Mongolia does not have adequate publishing companies, they don't even publish textbooks written in their own languages. Therefore professors teach classes using mostly based on their lecture notes and PowerPoint slides and make them available for students in the university library. Then a library worker makes copies and sells them to the students for their studies and exams. However, even though one copy of that is about $\$ 0.70$, students usually would not buy it. They think that's simply too expensive, because most part-time student workers are making about $\$ 3.00$ a day from work.

\section{RESEARCH BACKGROUND}

The author has experienced very valuable lesson as a college professor during a summer session in a Mongolian University a few years ago. With a humble mind of a Christian, I have volunteered to teach an Introduction to management information systems (MIS) course for Internet Business majors of a university located in Ulaanbaatar, Mongolia. I have prepared the class the same way as I teach a MIS class in my university back in the United States. Right after finishing my summer classes in the States, I flew to Mongolia and arrived in the university a few days earlier the class begins.

At the beginning, I had 26 students in my class. And some of students attended my class once, some other a few days, and still some several days As a result 15 students remained and took a mid-term exam. After the mid-term, student attendance was decreased to 12 students. No students have textbook and some of the students usually come to class late in 10 minutes or sometimes up to 30 minutes.

There were some serious problems in teaching adequate level of college classes there in that university: First, students are generally not ready for the college level of study because of that nation's education system completes elementary school to high school in 11 years rather than in 12 . In that university lectures are taught and delivered in three different languages: Mongolian, Korean, and English. When a lecture is in Korean, a Mongolian interpreter translated it into Mongolian in a class and vice versa. A main problem is that the students were not in fluent in Korean, nor English, but there were not enough Mongolian professors who can teach classes the university offers. Third, students come to a class without a textbook; they depend on professor's PowerPoint slides and lectures notes provided to the university library, the notes are being copied, and then purchased by students. Fourth, there are not enough professors who can teach major curriculums throughout the university. Lastly, they are not attending class regularly; some are coming on time, but mostly are coming to class far late. As a second objective, this research aimed to find a way to solve those identified critical problems by designing distance learning environment or e-Learning environment for the university with blended approach of open resources and tools available. It may not solve all of the problems, but it may solve some of the problem.

\section{DISTANCE LEARNING ENVIRONMENT WITH OPEN RESORUCES AND TOOLS}

\section{Distance Learning Environment}

According to a Mongolian statistics, there are 200 colleges and universities throughout the nation, which are usually small in size, some in less than 100 students. Some of them have been established by Christian missionaries and organizations. The author taught at one of those Christian universities. Most professors teach five different courses of 15 semester hours. At the same time, they have to advise students for academic, financial and spiritual matters by teaching Bible in the afternoon time. In addition, some faculty members have their own local churches to preach and minister.

In order to recruit more volunteers to teach for this university students, distance learning environment seems to be a best alternative. Marina Moisseeva [4] with Institute of International Education (IIE) classified different types and forms of distance learning environments: Courses, built on the basis of case-technologies and new information technologies, broadcasting courses, educational forums teleconferences and videoconferences, courses on the basis of computer assisted instruction, and Internetbased online courses. This article is based on the last option of the Internet utilizing distance learning model or Internet-based online course. Using the model, those volunteers from Korea or the U.S. do not need to travel to Mongolia or Cambodia and teach without leaving their places, thereby not spending thousands of dollars for traveling from America to Mongolia, and vice versa. In addition to the airline expenses, volunteer professors may need to prepare their living expenses occurring while they are teaching in that country.

There will be a lot of different types of online course infrastructure each volunteer professor can use to 
teach an Internet-based online course. First, one can use his or her own university's WebCT or eLearning facility by getting permission from his or her own university. Second, a professor uses his or her own commercial Website to deliver lectures for students in a third world country. Last method is using, for example, a Mongolian University's online system to teach the subject matters to those university students.

\section{AN ONLINE TEACHING MODEL}

For this online teaching model, as shown in Figure 1, as an example, information systems major curriculum framework is designed. This framework is integrated with three fundamental areas of business school focuses: business fundamentals, analytical \& critical thinking, and interpersonal, communication, and team skills. The IS program curriculum in the business school will utilize the following components. First, as a physical delivery method of knowledge and skills, the Internet-based online teaching infrastructure will be used. Second, The Global Text Project and other free textbooks resources such as Textbook Revolution, free book centre, etc. will be used for textbook providing resources for students and teachers in the $3^{\text {rd }}$ world countries. Third, Internet Public Library (IPL) and Harvard-Google Project will also provide students with plentiful of resources students need for their studies. Lastly, MIT Open CourseWare is another excellent resource students can take advantage of even though MIT does not offer any credit courses with this program.

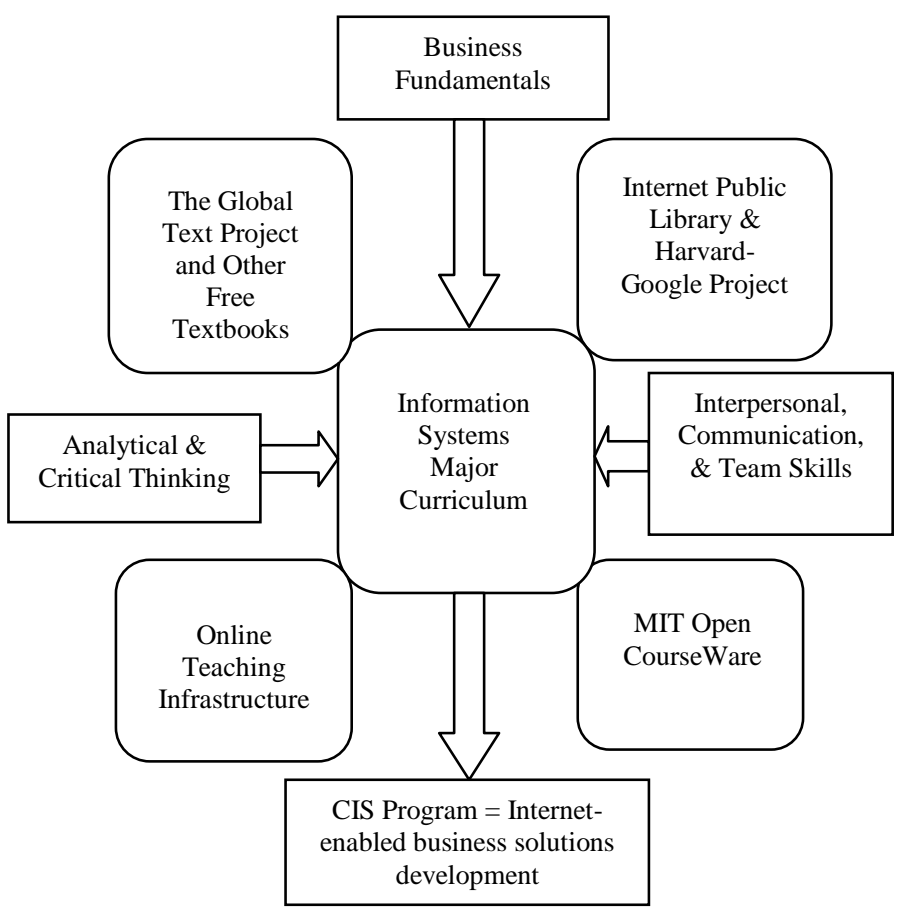

Figure 1: Information Systems Major Curriculum Framework

\section{EDUCATIONAL TOOLS ON THE INTERNET}

\section{The Global Text Project}

Former South African president, Nelson Mandela once said that "Education is the most powerful

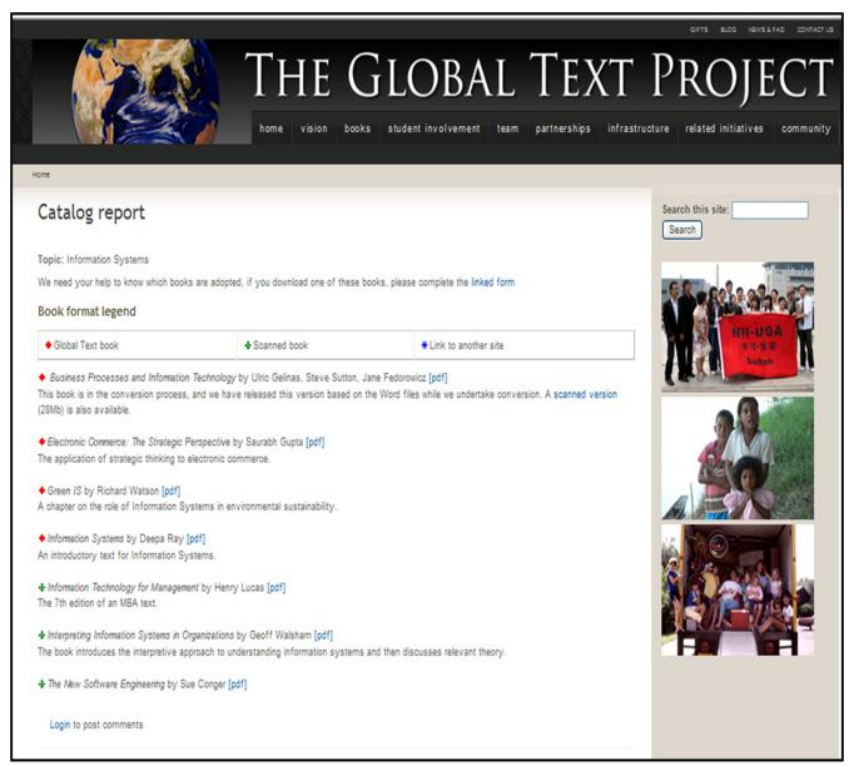

Figure 2: The Global Text Project Homepage

weapon you can use to change the world" [5]. As an international faculty, I feel exactly the same thing while living in Korea or in the U.S. To meet this slogan, professors from 46 colleges and universities around the world organized Global Text Project as shown as a Website in Figure 2, which are initiated by two professors of Dr. Don McCubbrey at University of Denver and Rick Watson at University of Georgia, respectively. The organization has planned to write at least 1,000 free electronic textbooks for students everywhere in the world. These books under Creative Commons License provide with the following categories of books: business, computing, education, health, humanities, natural sciences, and social sciences [6].

Dr. McCubbrey, co-project leader of the organization said that "Global Text Project is an inter-university project engaging the worldwide academic and practitioner communities in the development of free open-content textbooks in all undergraduate university disciplines targeted at students in the developing world" [7]. That is, Global Textbook Project's goal is to create college textbooks by 
students, professors, and practitioners and make them available to those who cannot afford buying their own textbooks.

Any person, who is interested in downloading any of those books listed based on its subject area, can download the textbook file. To download a selected book file, in the home page of The Global Text Project, click books tab, and select one or more categories in the Search box. In this case, I have selected, for example, Information Systems, and then

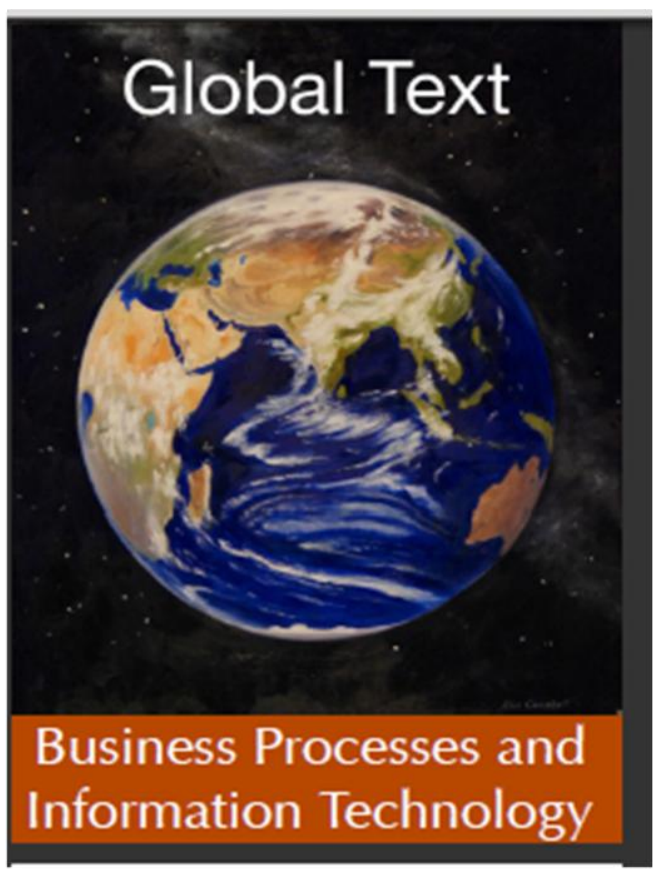

\section{Figure 3: Cover Page of Downloaded Book}

click the Submit button. As shown above in Figure 2 as a screen shot of that website, you will see Catalog Report as a heading. Next you will see three book legends: Global text book, Scanned book, and Link to other site. I have selected a book named Business

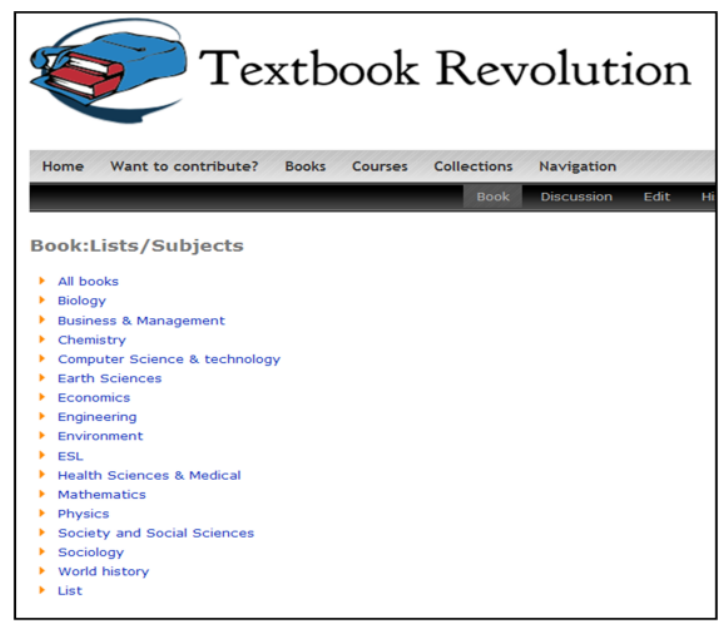

Figure 4: Cover Page of Textbook Revolution Volume XI, No. 2, 2010
Processes and Information Technology by Ulric Gelinas, Steve Sutton, and Jane Fedorowicz in the Global text book. Then I selected PDF file format of the book, which consists of 952 pages, shown with the cover page of the book in Figure 3 [8]. This Website is available in Arabian and Spanish languages too. As of April 26, 2010, a total of 64 textbooks are available in this site. In the information systems topic, there are 7 books listed.

Textbook Revolution

This is another free textbook website, which has links of free textbooks for college and university students, especially for the third world countries. This organization attempts to collect all free textbooks available in one place so that they can be used in the college classrooms around the world. If you click Books by Subject tab in its homepage, it takes you to a webpage which lists 15 different subject categories as shown in Figure 4. For example, I selected Computer Science and Technology subject [9]. In order to go through the downloading experiments, I clicked a book titled Business Information Systems in the List of All Computer Science page. As a next step, it took me to another webpage which shows author's biographical data, book's abstract, and its link to download the book file. I continually followed the steps by clicking the download link, it, then, took me to a different website called BookBoon.com. To download the book file from that

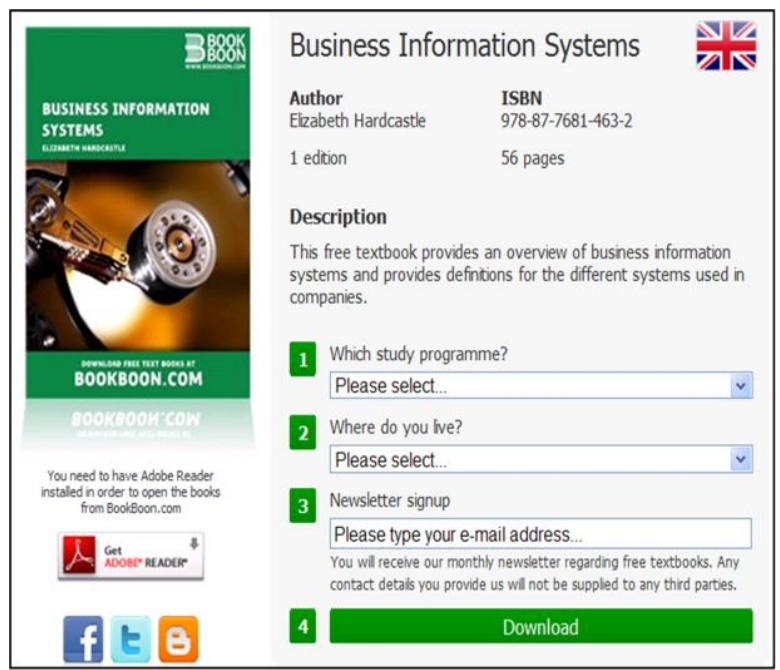

Figure 5: BookBoon Free Textbook Website

site, I had to answer three questions as shown in Figure 5, such as which study programme?, Where do you live?, and Newsletter signup. This site lists 27 different textbooks subjects [10]. In IT subject alone, there are 16 textbooks ready to be downloaded, and 2 more books are forthcoming soon. 


\section{Internet Public Library (IPL)}

The Internet Public Library (IPL) opened in 1995 as a non-profit organization. The IPL was originally founded by graduate students of Information Science majors at the University of Michigan. Since January 2007, the IPL is run by a consortium of 15 colleges and universities including University of Michigan and is hosted by graduate students of Information Science and Technology at Drexel University. According to its Website as shown in Figure 6, IPL2 is a new face of integration between the Internet Public Library and the Librarian's Internet Index. IPL2 is a public service organization and learning and teaching environment. On its homepage, it has five categories listed: Resources by Subject, Newspapers and Magazines, Special Collections Created by ipl2, For Kids, and For Teens. For Resources by Subject, there are 11 categories, which provide high quality of Internet resources. In summary, it provides useful, accurate, and factual information on these topics as follow:

- Arts \& Humanities

- Business and Economics

- Computers and Internet

- Education

- Entertainment and Leisure

- Health and Medical Sciences

- Law, Government, \& Political Science

- Reference

- Science and Technology

- Social Sciences

- Regional and country Information

For example, in Special Collection Created by ip12, it has two parts: most popular collections and other collections. In most popular collections has A+ Research Guide/Writing, which is very good for high

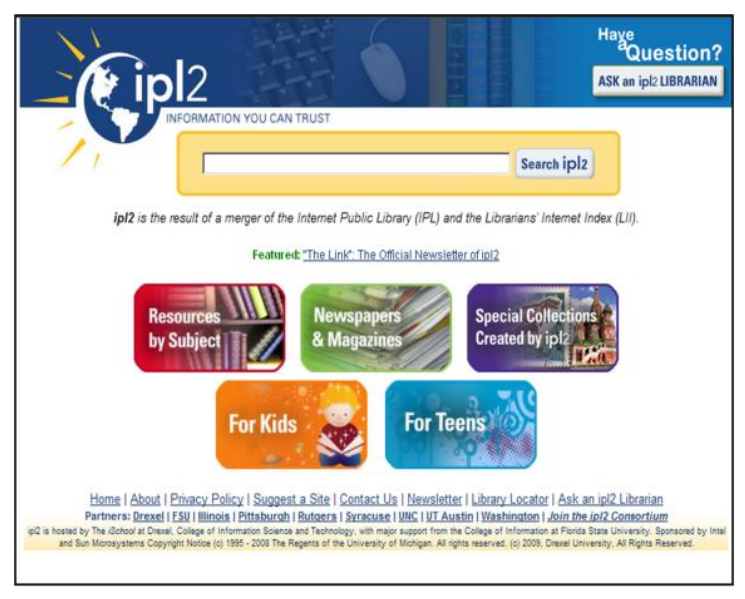

Figure 6: The IPL2 Homepage

Volume XI, No. 2, 2010 school and college students. From Other Collections, Web Technologies section contains a lot of useful resources to make website creating [11].

\section{Free Book Centre.Net}

This is another great website for free books available for any students who want to use for their studies. It

\begin{tabular}{|c|c|c|c|c|}
\hline \multirow{2}{*}{\multicolumn{2}{|c|}{ FreeBookCentre. Net }} & \multicolumn{3}{|c|}{$\begin{array}{l}\text { Freebookcentre.ente contains links to thousands offree online technical books. Which } \\
\text { Indude core computer science, networking, programming languages, Systems } \\
\text { Programming books, Linux books and many more. You are welcome to follow the } \\
\text { following links for the tree books tour. } \\
\text { Home } \quad \text { Feedback Broken Link Contact Us About }\end{array}$} \\
\hline & & Home $\quad \underline{F e}$ & edback Broken Link & $\underline{\text { Contact Us }} \underline{\text { About }}$ \\
\hline \multicolumn{5}{|l|}{ Computer Science } \\
\hline $\begin{array}{c}\text { Data } \\
\text { Structure/Algorithms } \\
\end{array}$ & Compiler Design & $\underline{000 / 00 P}$ & Programming Theory & Numerical \\
\hline Operating Systems & Computation Theory & Languages & Artificial Intelligence & Functional \\
\hline Architecture & Computer Science & Misc & & \\
\hline \multicolumn{5}{|l|}{ Computer Languages } \\
\hline$\underline{c}$ & $\underline{\mathrm{C}++}$ & XMLXSL & $\underline{\text { Icl/Tk }}$ & $\underline{U M L}$ \\
\hline $\begin{array}{l}\text { Programming } \\
\text { Languages }\end{array}$ & Perl & Python & $\underline{\text { Ada }}$ & $\underline{\text { Lisp }}$ \\
\hline Assembly Language & Fortran & Basic & Cobol & Ruby \\
\hline$\underline{\text { Scheme }}$ & Languages & Misc & $\underline{C P P}$ & CProgramming \\
\hline \multicolumn{5}{|l|}{ Java \& J2EE } \\
\hline Core Java & Advanced Java & $\underline{\text { J2EE/EJB }}$ & Jakarta Struts & $\underline{\text { Senvlet/JSP }}$ \\
\hline Spring/Hibernate & Design Patterns & Enterprise Java & $\underline{\text { Security }}$ & Distributed \\
\hline GUII & Multimedia & $\underline{I 2 M E}$ & Java//2ee & \\
\hline \multicolumn{5}{|l|}{ Linux \& Unix } \\
\hline Core Linux & Core Unix & FreeBSD & $\underline{\text { Security }}$ & Shell Programming \\
\hline Unix Networking & $\begin{array}{l}\text { Unix/linux } \\
\text { Programming } \\
\text { reging }\end{array}$ & System Administration & GUIX Windows & Regular Expression \\
\hline Iext Editing & $\underline{\underline{U n i x} \times \operatorname{Linux}}$ & & & \\
\hline \multicolumn{5}{|l|}{ Cisco Certification } \\
\hline Cisco Centification & CCNA Books & CCNP Books & CCIE Books & Other Cisco \\
\hline
\end{tabular}

Figure 7: FreeBookCentre.Net Homepage

equips especially with collections of thousands of online technical books. It contains 17 categories of books such as computer science, networking, computer programming languages, system programming, Linux, Cisco certification, web and Internet technologies, graphics and web development tools, other computer topics, mobile technologies, database systems and management, mathematics, physics, Microsoft Technologies, electronics, etc., as shown in Figure 7 [12]. As I selected database books, it contains a lot of books for SQL, Informix, Sybase, MySQL, PL/SQL, Oracle, DB2, database systems, and SQL Server. In database systems, 24 books are listed. As I clicked the Web link to Introduction to Database for the Webs, it took me to Web Developers' Virtual Library, where I found each textbook contains a full amount of contents like students buy from the textbook publishing companies. I also clicked SQL Server link, which was connected to a list of seven textbooks of SQL Server related topics [13]. 


\section{Textbook\Media.com}

This website contains the following textbooks: accounting, business/law, computer applications, economics, education, English, ethics, finance, mathematics, political science, psychology, and study and productivity tools. However, this site sells downloadable books at a discount price of $\$ 9.95$ plus online lecture notes. TextbookMedia.com is also a partner of open education resource with the Global Text project [14].

\section{MIT OpenCourseWare}

Under the slogans of "Unlocking Knowledge, Empowering Minds," this website contains 1,900 open courses available for anybody who wants to take without registration. Out of 20 most visited courses, introduction to computer science is one of them. Sloan School of Management offers 22 courses since spring 2002. Some of those courses are translated into five languages: traditional Chinese, and simplified Chinese, Thai, Portuguese, and Spanish. For example, Data Mining course is available with syllabus, calendar, selected lecture notes, exams with no solutions, assignments with no solutions and other study materials.

Students can download class materials from the Website and follow the class schedule which mostly has two sessions per week, and one session lasts for an hour and half. Another course, for example, Introduction to Algorithm, provides students with a complete set of lectures notes along with videos, and assignments with its solutions, and reading lists [15]. However, the OpencourseWare does not offer any credit-bearing or degree-granting courses through this project.

\section{Harvard-Google Project}

Google Books Library Project started initially with Harvard Universities, University of Michigan, Stanford University, New York Public library, and Oxford University in England. In particular, Harvard-Google Project has been building a pilot library program successfully.

This project provides students and professors with enormous opportunities to access one of the most privileged university library books in the world [16]. Through this new model of the digitized books, this project may benefit countless number of learners and teachers around the world.

\section{WikiBooks Website}

WikiBooks website is another open-content textbooks collection. With a banner of "Open books for an open world," it began on July 10, 2003 with a simple thought that any student can use the textbooks available in this site. Books by subject are the toplevel classifying method; it has nine subject areas: natural sciences, social sciences, computing, humanities, mathematics, language, engineering, standard curricula, and miscellaneous. Out of computing subject area, I clicked information technology area. In these books of information technology area, they are listed as follows: books completed, books nearing completion, half-finished books, partly developed books, freshly started books, and unknown completion. In the books completed group, as I selected a book called "Applications of ICT (information and communication technologies) in libraries," it took me to next webpage, which showed more detailed contents of nine categories of the books. From these categories, I clicked the Diploma ICTL (ICT in libraries), which displays the contents of the book [17].

\section{CONCLUSION}

This paper was designed with two ideas: one is to let any professors know about opportunities to teach students in the third world countries during their summer vacation time or sabbatical period. The other was to design a distance learning environment for those students with open books, and open libraries available in the Internet. As a Christian professor living in the United States, I feel I have been blessed more than I expected to have. Thus, the author believes that there are many more professors and researchers participating in the annual conference may share the same thoughts with me. As of May 2010, the author thinks about particularly two universities, which are needed a lot of help and support from us: one is in Mongolia and the other is in Cambodia. Both of them are Christian universities. Any applicants, Christian believers or not, can apply for the universities and attend them. At the same time any scholars, researchers, and even graduate students can volunteer for these two universities to teach students, for example, for a week, a month, a semester, or a year depending on their availability. Any of us can impact on students there.

You can teach students in the traditional face-to-face classroom or via online course. Even though administrators and students in the universities may prefer the face-to-face teaching method, most of us cannot afford going physically to the universities. 
That is why as an alternative way, this research attempted to utilize the Internet-based knowledge and skills delivery system along with open resources available in the Internet, which is aimed at the students in the third world countries. Tom Russell indicated in his research that effectiveness of distance education via a variety of delivery modes has the "same or even better than" traditional classroom learning and teaching [18].

\section{REFERENCES}

1. Mongolia: Official Tourism Website of Mongolia, http://www.mongoliatourism.gov.mn/

2. Robert Sedgwick (2003). World Education News and Reviews: Education in Mongolia, http://www.wes.org/ewenr/03july/Practical.htm

3. Wikipedia, The Free Encyclopedia: Mongolia, http://en.wikipedia.org/wiki/Countries_of_the_world

4. Marina Moisseeva, Institute of International Education (IIE) Network: Types and forms of distance http://www.iienetwork.org/?p=41544

5. Nelson Mandela, Finding Quotations was never this easy: Nelson Mandela Quotes, http://thinkexist.com/quotation/education_is_the_mos t_powerful_weapon_which_you/144638.html

6. The Global Textbook Project, http://globaltext.terry.uga.edu/books

7. Du Portfolio, Don McCubbrey: Biographical Description, https://portfolio.du.edu/pc/port?portfolio=dmccubbr 8. The Global Textbook Project: Partnership, http://globaltext.terry.uga.edu/partnerships

9. Textbook Revolution: Main page, http://textbookrevolution.org/index.php/Main_Page

10. BookBoon.com, http://bookboon.com/us/student/management/busines s-information-systems

11. ip12: Information you can trust, Internet Public Library, http://www.ipl.org/

12. FreeBookCentre.Net: The Collection of Free Books on the Web, http://freebookcentre.net/

13. Web Developers' Virtual Library: Introduction to Databases for the Web/Table of Contents, http://wdvl.com/Authoring/DB/Intro/toc.html

14. TextbooklMedia, At Textbook Media - Students have options, http://www.textbookMedia.com
15. MIT OpenCourseWare: Unlocking Knowledge, Empowering Minds, http://ocw.mit.edu/OcwWeb/web/home/home/index.h tm

16. Harvard University Library: Harvard-Google Project, http://hul.harvard.edu/hgproject/index.html

17. WikiBooks, Open books for an open world, http://en.wikibooks.org/wiki/Eac3to/How_to_Use

18. Tom Russell, The No-Significant-Difference Phenomenon, http://nt.media.hku.hk/no_sig_diff/phenom1.html 